\title{
Trachemys callirostris (Gray 1856) - Colombian Slider, Jicotea, Hicotea, Galapago, Morrocoy de Agua
}

\author{
Brian C. Bock ${ }^{1}$, Vivian P. Páez ${ }^{1}$, And Juan M. Daza ${ }^{1}$ \\ ${ }^{1}$ Instituto de Biología, Universidad de Antioquia, Medellín, Colombia \\ [BrianBock1@gmail.com; vivianpaez1@gmail.com; jdaza@biologia.udea.edu.co]
}

\begin{abstract}
Summary. - The Colombian slider, Trachemys callirostris (Family Emydidae), is a moderatesized turtle (carapace length to $33 \mathrm{~cm}$ ) endemic to northern South America, with two recognized subspecies: T. c. callirostris in northern Colombia and northwest Venezuela, and T.c.chichiriviche further east along the Venezuelan coast. The two subspecies are distinguished by various aspects of their coloration and the structure of the second neural bone. There also may be differences in adult sizes, with $T$. c . callirostris being atypically small for a tropical slider turtle, but this may reflect the intense hunting pressures nesting females of this subspecies experience in most areas of its distribution. Trachemys callirostris is sexually dimorphic, with females being larger. While different populations may differ in mean body size, morphometric and genetic studies have provided no evidence for significant intra-specific variation besides the morphological differences between the two subspecies. These turtles are habitat generalists, omnivores, and bask frequently, but little else concerning their demography or non-breeding ecology is known. Nesting occurs during the dry season (December-May) and eggs are usually buried under low vegetation in moist soil near the shoreline. Clutch size depends on female size, and varies from 1-23 eggs. Predation on eggs and egg incubation failure is common. A study of incubation temperatures in natural nests found that with a mean incubation temperature of $31.7^{\circ} \mathrm{C}$, all neonates produced were females, implying the species has temperature-dependent sex determination. Adults and nests are exploited throughout the range of the species, and despite protection by national legislation and the existence of several protected areas within the range of the species, current levels of exploitation probably are not sustainable. Enforcement of existing legislation and demographic monitoring are needed.

Distribution. - Colombia, Venezuela. Distributed in the Magdalena and Sinú river drainages in northern Colombia, around Lake Maracaibo in northwest Venezuela, and east along the Venezuelan coast in the states of Falcón and Carabobo.

Synonymy.-Emys callirostris Gray 1856, Callichelys callirostris, Pseudemys callirostris, Chrysemys ornata callirostris, Pseudemys scripta callirostris, Pseudemys ornata callirostris, Chrysemys callirostris, Chrysemys scripta callirostris, Trachemys scripta callirostris, Trachemys callirostris, Trachemys ornata callirostris, Trachemys dorbigni callirostris, Trachemys callirostris callirostris.

SuBSPECIES. - Two currently recognized: Trachemys callirostris callirostris (Colombian Slider) and Trachemys callirostris chichiriviche (Venezuelan Slider) (synonymy: Pseudemys scripta chichiriviche Pritchard and Trebbau 1984, Trachemys scripta chichiriviche, Trachemys ornata chichiriviche.

STATUS. - IUCN 2009 Red List: Near Threatened (LR/nt; as Trachemys scripta, sensu lato) (assessed 1996, needs updating); CITES: Not Listed; Colombia Red Book: Near Threatened.
\end{abstract}

Taxonomy. - First described as Emys callirostris by Gray in 1856 with a type locality of "America", Müller (1940) restricted the type locality to "Magdalena River, Colombia". Boulenger (1889) demoted the taxon to subspecific status, where it underwent several generic and specific name changes. Pritchard and Trebbau(1984) recognized Pseudemys scripta callirostris and described a second subspecies (P.s. chichiriviche). Seidel (2002) proposed elevating Trachemys callirostris to specific level again based upon an analysis of morphological data, while retaining both subspecies. While not providing independent support for Seidel's (2002) proposal, a subsequent molecular analysis (Jackson et al. 2008) also did not yield results that justified challenging species-level status for $T$. callirostris, and thus Seidel's
(2002) taxonomy currently is retained (TTWG 2007; Fritz and Havaš 2007).

Trachemys callirostris is one of four South American Trachemys species, including the biogeographically disjunct T. dorbigni from southern Brazil and northern Argentina, the isolated T. adiutrix from northeastern Brazil, and the Central American T. venusta that barely enters northwest Colombia. The phylogenetic relationships within the genus Trachemys are not entirely clear (Jackson et al. 2008). In the case of $T$. callirostris, the morphological analysis of Seidel (2002) suggested that its closest relative is T. stejnegeri that occurs on Antillean islands to the north of Colombia and Venezuela. Using a more comprehensive morphological data set, Stephens and Weins (2003) identified T. venusta as the 


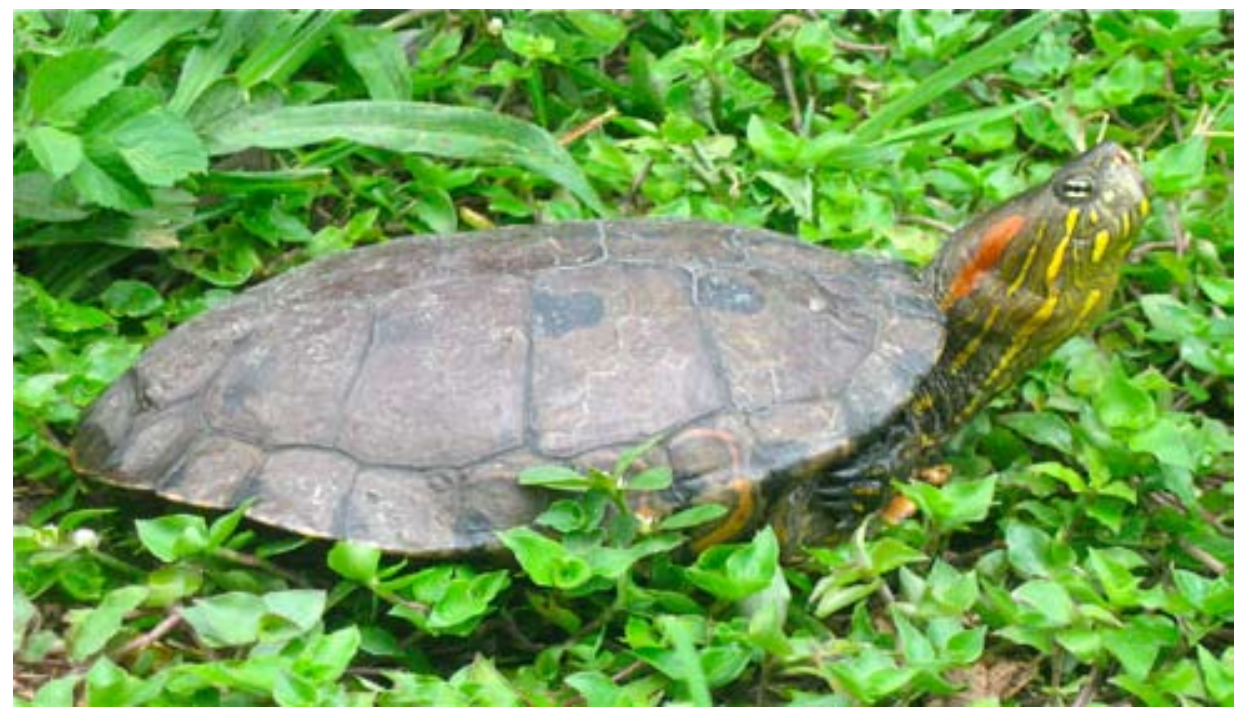

Figure 1. Trachemys callirostris callirostris, adult female from Colombia. Photo by Vivian P. Páez.

sister taxon to T. callirostris, and molecular data appear to corroborate this hypothesis (Jackson et al. 2008).

Description. - The most complete description of the two subspecies of T. callirostris can be found in Pritchard and Trebbau (1984) and is summarized here. Adult T. callirostris are moderately sized sliders not known to exceed 33

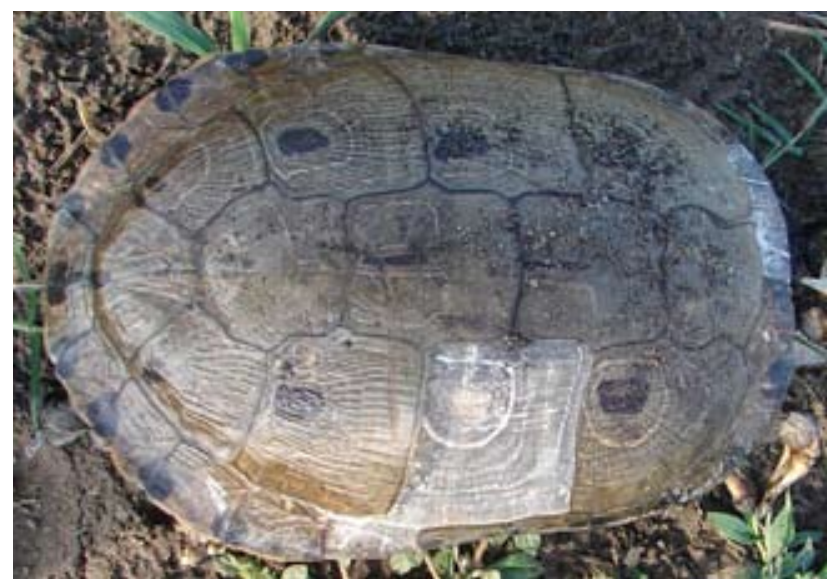

Figure 2. Trachemys callirostris callirostris, adult female shell from Colombia, showing carapacial markings. Photo by Museo de Herpetología de la Universidad de Antioquia.

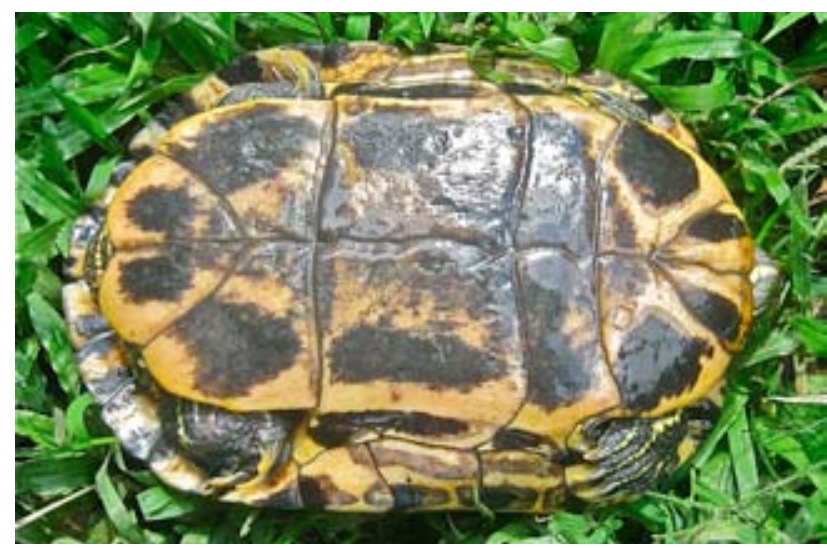

Figure 3. Trachemys callirostris callirostris, adult female from Colombia, showing plastral markings, same animal as Fig. 1. Photo by Vivian P. Páez. $\mathrm{cm}$ carapace length (CL) or $5 \mathrm{~kg}$ in mass. The oval carapace is widest at the junction of marginals VII and VIII and it is either domed or flattened with the highest point at the rear of vertebral III. There are five vertebral scutes, four pairs of costal scutes, and 12 pairs of marginal scutes that have a smooth outer edge. The plastron is large, broad, and flat with a posterior notch. The wide bridge may be equivalent to as much as $40 \%$ of the total CL. The large rounded head has a slightly conical snout and is flat or slightly concave dorsally. There is sexual size dimorphism (Medem 1975; Sampedro-M. et al. 2003), with females being larger than males and having broader heads, higher carapaces, and thinner, shorter tails (but forelimb claws are not dimorphic, as in some other Trachemys species). Females also appear

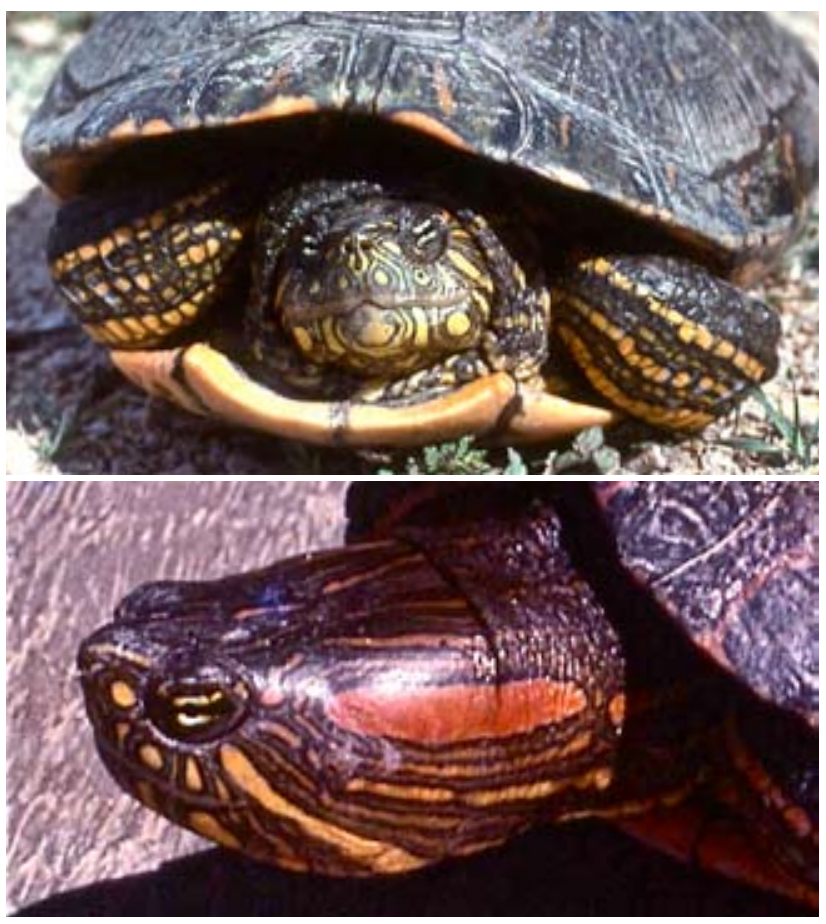

Figure 4. Trachemys callirostris callirostris, adult females from Colombia. Photos by Peter C.H. Pritchard. 


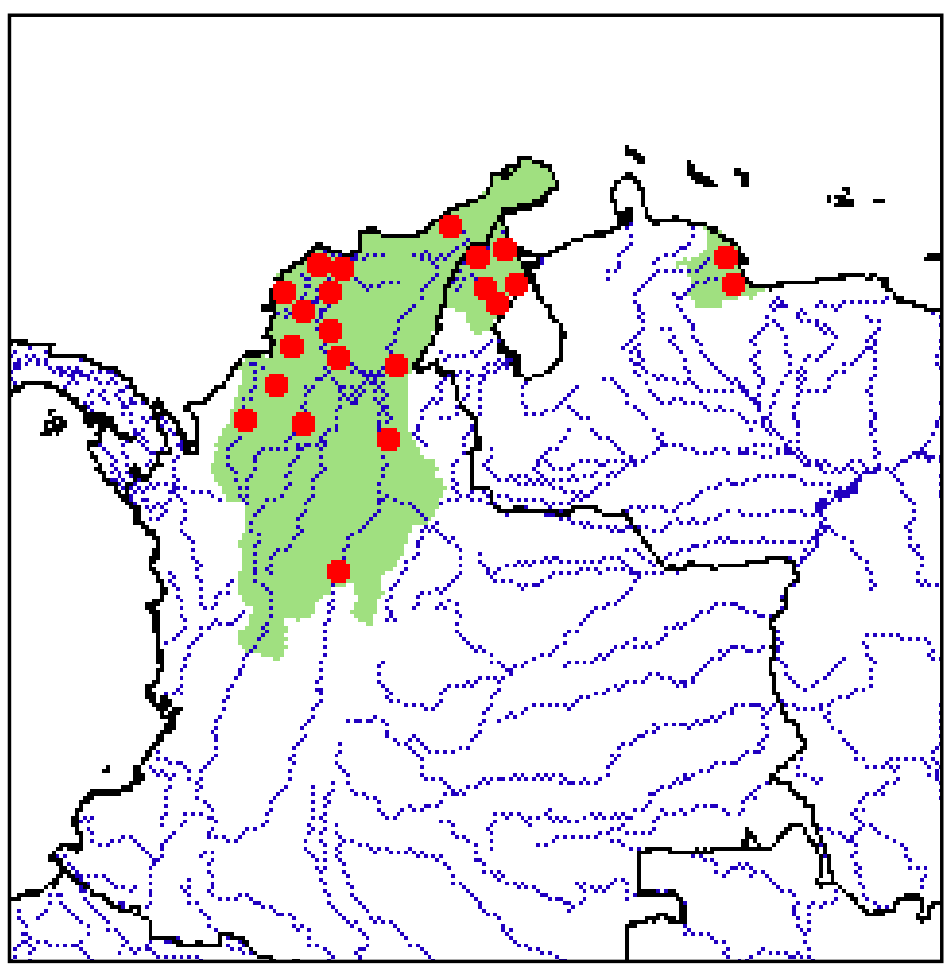

Figure 5. Distribution of Trachemys callirostris in Colombia and Venezuela in northwestern South America. Red points $=$ museum and literature occurrence records based on Iverson (1992) plus more recent and authors' data; green shading = projected distribution based on GIS-defined hydrologic unit compartments (HUCs) constructed around verified localities and then adding HUCs that connect known point localities in the same watershed or physiographic region, and similar habitats and elevations as verified HUCs (Buhlmann et al. 2009), and adjusted based on authors' data. The larger disjunct range in Colombia and western Venezuela is T. c. callirostris, the smaller disjunct range in central coastal Venezuela is T. c. chichiriviche.

to be more melanistic than males in some populations (Sampedro-M. et al. 2003).

Hatchlings emerge measuring approximately $30 \mathrm{~mm} \mathrm{CL}$ and $6.5 \mathrm{~g}$ in mass (Correa-H. 2006; Restrepo et al. 2007). Their carapaces are bright green with a pronounced black spot
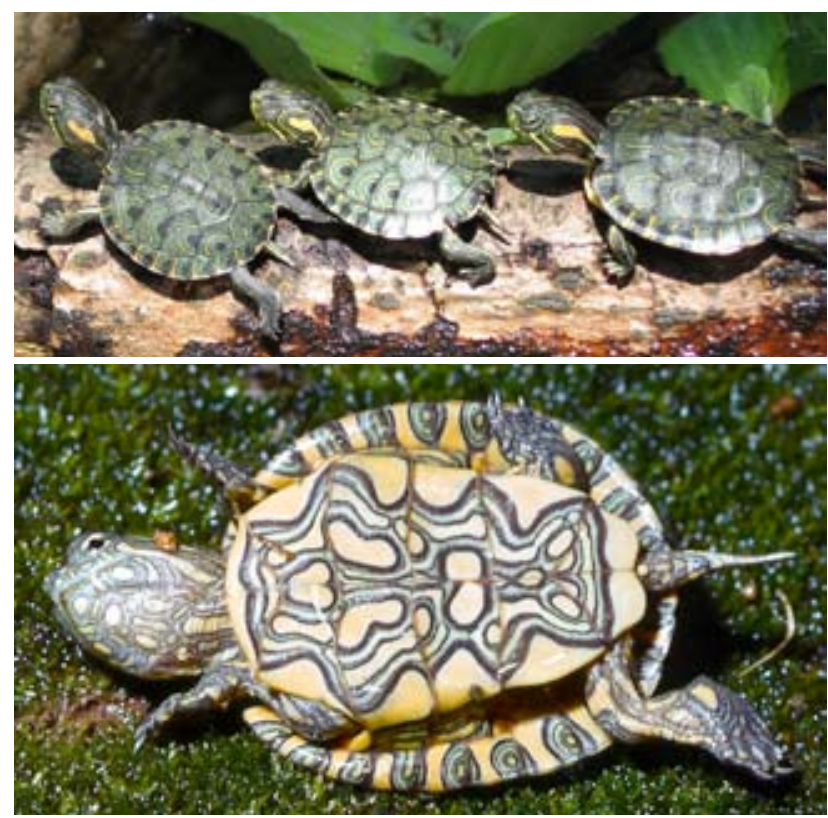

Figure 6. Trachemys callirostris callirostris, hatchlings from Colombia. Photos by Vivian P. Páez (top) and John Visser, courtesy of Peter C.H. Pritchard (bottom). in each vertebral and costal scute and in the lower posterior corner of each marginal scute. On each vertebral scute, the black spot is flanked by two broad, curved longitudinal stripes. The plastron contains a complex, largely symmetrical pattern of black markings that is variable among individuals. With growth, most of the markings on the carapace and plastron fade, except the black spots and yellow lines on the marginal scutes. In adults, the carapace is usually a uniform color (see subspecies descriptions below) although circular markings around each intermarginal seam persist. The plastron in adults usually loses its black pattern as well.

Pritchard and Trebbau (1984) distinguished between $T$. c. callirostris and T.c.chichiriviche based on six characteristics. The first was that adult T.c.callirostris were substantially smaller (19-25 cm CL) than adults of chichiriviche (28-33 cm CL), and of other neotropical slider species as well. However, that contrast was based upon measurements of 14 adult $T$. c. chichiriviche (of unknown sex) and an estimated 150 adults of T. c. callirostris. While the available sample size for the poorly studied T. c. chichiriviche subspecies has not increased to our knowledge, we and our students have recently measured over 1600 adult female T. c. callirostris from 14 different populations. Our results indicate that mean and maximum sizes of adult females in a population are influenced by both habitat conditions and the intensity of hunting pressures (Bernal et al. 2004; Daza 2004; Daza and Páez 2007). Pritchard and Trebbau (1984) reported that hunting of T.c. chichiriviche at the time they 

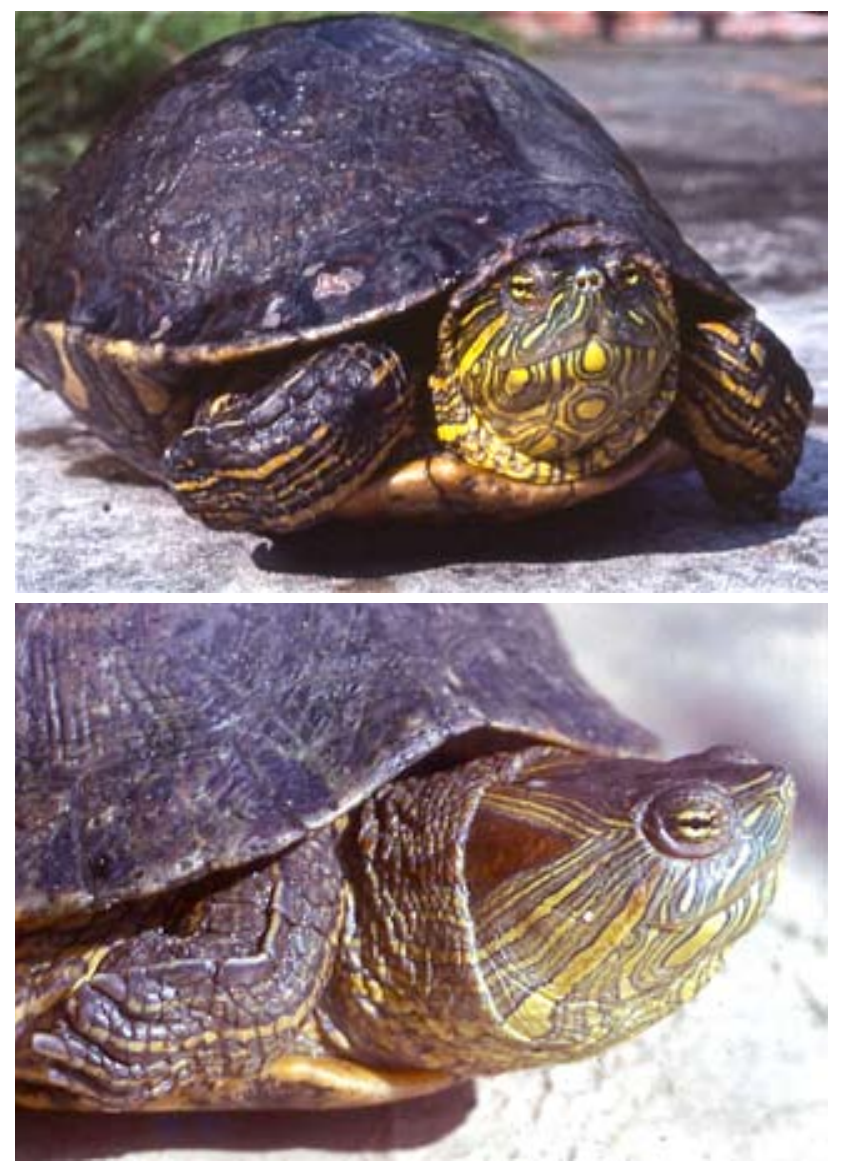

Figure 7.Trachemys callirostris chichiriviche, adult females from central coastal Venezuela. Note the diagnostic lack of maxillary ocelli and the presence of a wedge-shaped brownish-red post-orbital stripe. Photos by Peter C.H. Pritchard.

described the subspecies was principally for local domestic consumption, while most of our T. c. callirostris populations currently experience heavy commercial exploitation. Even so, we have documented a female T.c.callirostris of $31.5 \mathrm{~cm}$ CL (Daza 2004), well into the range reported for T. c. chichiriviche. Medem (1975) also reported female $T$. c. callirostris attaining $30 \mathrm{~cm} \mathrm{CL}$. When more size data for T. c. chichiriviche become available, it may well result that there is indeed a statistically significant difference in the size distributions for the two subspecies, but it will surely be more subtle than initially reported, and may be simply the result of the two subspecies occupying different habitats or experiencing different levels of exploitation.

The remaining characteristics that distinguish the two subspecies are: 2) post-orbital stripe bright red with parallel sides in T.c.callirostris vs. brownish-red to red and wedgeshaped in T. c. chichiriviche; 3) the plastral figure in T.c. callirostris is wide, intense and approaches or touches the bridge vs. in T. c. chichiriviche the figure consists of narrow lines near the plastral midline; 4) the carapace color of adult $T$. c. callirostris is olive or greenish vs. olive-brown to chocolate-brown in T. c. chichiriviche; 5) ocelli in T. . . callirostris are circular and present on the chin and maxillae vs. non-circular and only present on the chin in T. c. chichiriviche; and 6) the second neural bone in T. c.callirostris is always hexagonal vs. frequently octagonal or heptagonal in T. c. chichiriviche.

Martínez et al. (2007) genetically characterized six $T$. c. callirostris populations from the Mompos Depression of the Magdalena River drainage, using allozymes and a sampling design modelled after studies conducted on Savannah River Ecology Laboratory populations of T. scripta elegans (Scribner et al. 1984, 1986; Smith and Scribner 1990). While these earlier studies documented high levels of genetic variation and marked population structure in T. scripta elegans, Martínez et al. (2007) found low levels of genetic variability in T. c. callirostris and no evidence of allele frequency differences among sites separated by distances of from 20 to $57 \mathrm{~km}$. Additional allozyme analyses of samples obtained from the middle and lower Magdalena River drainage and San Jorge River (Bock, unpubl. data) again documented low levels of variation, but fixed allelic differences in two polymorphic loci showed the middle Magdalena River site to differ from the other two sites. Nevertheless, there is no evidence at present that evolutionarily significant units (ESUs) exist in T. callirostris, with the exception of the two recognized subspecies, although the geographically disjunct population of T.c. callirostris in Lake Maracaibo, Venezuela probably should be considered a separate management unit independent of the remaining Colombian populations of this subspecies.

Distribution. - Trachemys c. callirostris occurs in northern Colombia in the middle and lower Magdalena River drainage and its principal tributaries (lower Cauca and San Jorge rivers) and in other drainages such as the lower Sinú River (Ernst 2003; Rueda-Almonacid et al. 2007). It also supposedly once occurred to the west as far as La Marimonda wetland in the Gulf of Urabá and to the east to the Ranchería River (F. Medem, pers. comm. in Pritchard and Trebbau 1984), where it presumably has been extirpated. Today, $T$. c. callirostris appears to be allopatric with populations of $T$. venusta in northwest Colombia, with the two taxa separated by the Serranía Abibe that separates the T. venusta populations that inhabit tributaries of the Gulf of Urabá from the populations of T. c. callirostris along the Caribbean coast to the east. There also is a disjunction within the range of $T$. c. callirostris in the region of the Guajira peninsula on the border between Colombia and Venezuela, with T. c. callirostris populations in Venezuela only occurring in rivers that drain into the western portion of Lake Maracaibo in Zulia Province (Pritchard and Trebbau 1984). Legler (1990) also reported the distribution of T.c.callirostris as extending into Falcón State in Venezuela (near Puerto Cabello), but this seems unlikely, as it would imply sympatry with T.c. chichiriviche.

The subspecies T.c. chichiriviche has a more restricted distribution, occurring in coastal rivers between Río Tocuyo, Falcón State and Morón, Carabobo State along the Caribbean coast of northern Venezuela (Pritchard and Trebbau 1984).

Habitat and Ecology. - With the elevation of T. scripta callirostris to species status, Seidel (2002) converted this 
taxon from being just one of many subspecies of perhaps the best ecologically studied freshwater turtle in the world (Gibbons 1990), into being one of the least known species of slider turtles (Medem 1975). However, it is likely that much of what is known about the habitat preferences and ecology of other tropical and temperate zone Trachemys species will eventually prove to be generalizable to $T$. callirostris. The species appears to be a habitat generalist, occurring in virtually any permanent, slowly flowing lotic or lentic waters, including highly contaminated sites. However, tropical sliders appear to shun such habitat when it is surrounded by dense forest, presumably due to a lack of suitable nesting habitat (Moll and Legler 1971), but this is not a consideration for most $T$. callirostris populations, given the extreme amount of deforestation that has occurred, at least in northern Colombian. Stomach content analyses have confirmed that adult female T. callirostris are omnivorous (Lenis 2009) and we have even observed captive neonates biting each other to the point of causing the death of weakened individuals.

Recent studies have found two species of parasitic trematodes in the intestines of wild-caught adult females, one apparently representing a new species and another representing a first record for Colombia (Lenis 2009); as well as a new species of monogenean obtained from the buccal and cloacal cavities of these individuals (Lenis and Garcia-P. 2009). To date, nothing has been published concerning predation of adults except, of course, human predation.

In the Mompos Depression of the middle Magdalena River drainage, the complex spatial distribution of canals and wetland lakes means some $T$. callirostris habitats are more accessible to turtle hunters than others. Our studies have shown that differences among sites in habitat characteristics (principally the amount of annual rainfall) and levels of hunting pressure affect mean adult female body size, and hence also mean clutch size (Bernal et al. 2004; Daza 2004; Daza and Páez 2007). Populations from drier sites and from more heavily hunted sites had significantly smaller adult females that laid smaller clutches.

Nesting in the Mompos Depression has been documented to occur from February to May (Medem 1975; Bernal et al. 2004; Correa-H. 2006; Restrepo et al. 2006, 2007), although it is likely that nesting occurs throughout the main dry season (from December to May). Females also nest during the secondary dry season (veranillo, in July and August; Bock, unpubl. data). Nests are usually constructed near the shoreline (Medem 1975; Bernal et al. 2004; Correa-H. 2006; Restrepo et al., 2006), although nests located over $50 \mathrm{~m}$ from the nearest body of water have been documented (Medem 1975). Females select locations under herbaceous vegetation with moist soil for constructing their nests (Medem 1975; Bernal et al. 2004; Correa-H. 2006; Restrepo et al. 2006). In the 1966 nesting season, Medem (1975) found eight nests from the Ciénaga de Totumo in the Atlantico Department that contained from 11 to 23 eggs, mentioning reports that clutches of up to 30 eggs sometimes were harvested. Our more recent studies have yielded mean clutch sizes near the minimum clutch size reported by Medem (1975); Correa-H. (2006) documented a mean clutch size of 11 eggs (range 5-21 eggs) in 45 nests from Isla Pava in the La Rinconada wetland of the Magdalena Department, while 61 nests from Isla León in the Pijiño wetland complex of the same department yielded a comparable mean clutch size, with from one to $22 \mathrm{eggs}$ per clutch (Bernal et al. 2004; Restrepo et al. 2007). Clutch size was positively correlated to female size in 31 females from Isla Pava (Correo-H. 2006).

We studied nesting on islands where human predation rates are relatively low. Even so, nest predation rates in two years on Isla Leon were 23\% and 47\% (Bernal et al. 2004; Restrepo et al. 2007) and in one year on Isla Pava they were $83 \%$, with nest loss almost exclusively due to the lizard Tupinambis teguixin (Teiidae). Medem (1975) also reported raccoons (Procyon sp.), crab-eating fox (Cerdocyon thous), armadillos (Dasypus novemcinctus), and unspecified species of hawks and falcons as being capable of opening and depredating nests. His mention of green iguanas (Iguana iguana) in this context probably is incorrect, but both iguanas and sliders nest in open areas during the dry season in this region (Muñoz et al. 2003), and iguanas are known to occasionally dig into previously laid iguana and crocodile nests when excavating their nest burrows (Rand 1968). Iguanas also may excavate incubating $T$. callirostris nests, giving rise to the appearance of nest predation.

Hatching success rates of $T$. callirostris eggs not depredated in the two years of study in Isla León were $13 \%$ and $56 \%$ (Bernal et al. 2004; Restrepo et al. 2007) and were $31 \%$ in Isla Pava (Correa-H. 2006). Many, but not all, of the eggs that failed to hatch were infested with ants (genera Solenopsis, Crematogasater, Dorymyrmex, Camponotus, Paratrechinia), hemipterans (Family Cydnidae), adult and larval coleopterans (Families Tenebrionidae and Carabidae), and dipterans (Family Sarcophagidae). It is not clear whether these cases represent genuine instances of egg predation, or simply that these species opportunistically scavenge embryos that die for other reasons. In Isla Pava, $48 \%$ of all nests also showed evidence of infection by fungi (Trichocladium sp., Scedosporium apiospermum, Fusarium sp. Penicilium sp., and Chrysonilia sitophila).

Medem (1975) reported incubation periods in one transferred and three natural nests of from 69 to 93 days. In Isla Pava, 56 nests had a mean incubation period of 56 days (Correa-H. 2006), while in Isla Leon, 22 nests had a mean incubation period of 53 days (Restrepo et al. 2007). Medem (1975) also measured incubation temperatures in the three natural nests he encountered and reported a range of from 30 to $33^{\circ} \mathrm{C}$, while Restrepo et al. (2007) placed data loggers in 12 natural nests on Isla León; of which one was depredated and four others failed to hatch. Those that failed to hatch had significantly lower incubation temperatures, especially at the end of the incubation period, than those that produced hatchlings. Mean incubation temperature in the nests that hatched was $31.7^{\circ} \mathrm{C}$ (individual nest means ranged from 31.0 to $32.6^{\circ} \mathrm{C}$ ). The neonates obtained were sexed by histology $(n=42)$ or by inspection of the external 
morphology of their gonads $(n=38)$, and in both cases, all were determined to be females, strongly suggesting the existence of temperature-dependent sex determination in this species. Controlled laboratory studies will be needed to determine the actual threshold temperature for this and other $T$. callirostris populations.

Population Status. - Besides the anecdotal mention of the possible extirpation of populations of T.c.callirostris in the Gulf of Urabá and Ranchería River in Colombia (Pritchard and Trebbau 1984), information on the demographic status of $T$. callirostris populations is completely lacking. However, information on the magnitude of the harvest of adult female T. c. callirostris in Colombia each year (see following section) implies densities in the source populations must be high, as has been documented for other tropical slider species (Iverson 1982; Moll 1990). Residents of areas where the species occurs often reported that population abundances had declined due to over-harvest (Fuentes et al. 2003). For example, hunters from the Cocota wetland in the lower Cauca River drainage reported once being able to harvest up to 300 T.c.callirostris individuals each month, but complained that harvests rates have dropped to a tenth of that value (Aguilera-G. 1998).

Additional evidence that over-exploitation, especially of adult females, has affected T. c. callirostris populations comes from several of our studies that have shown a negative correlation between estimates of hunting pressure and mean female size (Bernal et al. 2004; Daza 2004; Daza and Páez 2007), a phenomenon also documented in T. scripta. elegans (Close and Seigel 1997).

Threats to Survival. - Undoubtedly the single greatest threat to the species throughout its range of distribution is human exploitation. Adults of both sexes are harvested incidentally in fishing nets and also are targeted specifically in hunting forays, using a variety of techniques (Fuentes et al. 2003). During the nesting season, females on land are hunted with dogs and any nests encountered are excavated and the eggs consumed. In northern Colombia, T. c. callirostris is the most heavily exploited of all wildlife species, with an estimated $30 \%$ of the harvested adults consumed locally and the remaining turtles sold in markets in the larger cities (De la Ossa 2003). It is estimated that over one million T.c. callirostris are harvested annually in the Mojana region in the Sucre Department of Colombia each year (Aguilera-G. and Neira-M. 1999; De la Ossa 2003). In a different rural area of the same Department, it has been documented that half of all residents participate in turtle hunting activities; if a similar proportion holds for the Mojana region, that has an estimated rural population of 75,000 inhabitants (Santos and Huertas-A 2003), it would imply that an average turtle hunter there harvests 27 adult individuals annually. Juveniles are also harvested and sold as pets (Methner 1989).

Environmental contamination and habitat alteration also probably have influenced the distribution and local abundances of T. callirostris. For example, in the Sinú River of Colombia, the Urra I Hydroelectric Project has altered the natural hydrological cycle, reducing the volume of water in wetlands associated with the river. Releasing water during the dry season also causes nest loss in downstream beaches and river banks due to flooding (Bernal 2003).

Despite Venezuela having native populations of T.callirostris,T.s.elegans hatchlings have been imported there for the pet trade (Pritchard and Trebbau 1984; Warwick 1986) and introduced populations have been established (T. Barrios, pers. comm.), raising the possibility of either ecological competition with, or genetic contamination of, both native subspecies of T. callirostris. In Colombia, confiscated T.c. callirostris individuals are commonly released into natural populations without knowing their sites of origin, potentially leading to genetic mixing of divergent management units, although no evidence of substantial genetic structure among Colombian populations was revealed by allozyme studies (Martinez et al. 2007).

Conservation Measures Taken. - The IUCN Red List classification requires updating, given that it still retains $T$. scripta sensu lato (Ernst 1990) as a single, highly variable species that contains 14 recognized subspecies, including T. s. callirostris and T. s. chichiriviche. The 1996 IUCN assessment of this wide ranging polytypic species was "Lower risk/near threatened". In Colombia, the subspecies T. c. callirostris has recently been listed on the national Colombia Red Book as Near Threatened (Castaño-Mora 2002), using version 3.1 of the IUCN criteria (Gärdenfors et al. 2001). Moreover, Colombian Resolution 219 issued by INDERENA in 1964 specifically prohibited the commercial harvest of $T$. c. callirostris and Resolution 126 issued by the Corporación de los Valles de los Ríos Magdalena y Sinú prohibited the collection of T.c.callirostris eggs within its area of jurisdiction and set size limits for subsistence hunting. Article 252 of Decree 1608 of 1978 states that permits are not required for subsistence hunting of wildlife in Colombia, but warns it must be conducted in a sustainable manner. In Venezuela, Article 48 of the "Ley Orgánica del Ambiente" defines priorities for receiving protection status, with one criterion being "rare species or populations of singular ecological value." Presumably, this applies to both the T. c. callirostris and $T$. c. chichiriviche populations in Venezuela.

Despite such national legislation, commercial harvest of $T$. callirostris populations persists, presumably due to the combined effects of the pressing economic needs of the majority of residents of this region, their lack of economic alternatives, an insufficient level of environmental awareness, and inadequate enforcement of the existing legislation by regulatory authorities. The only concrete conservation measures that occur in Colombia are occasional confiscations when local authorities encounter intermediaries transporting turtles to markets. For example, De la Ossa (2003) reported that between 1996 and 2002 in the Mojana region of the Mompos Depression, over 32,000 turtles were confiscated and released. More recently, the Ministerio de Ambiente, Vivienda y Desarrollo Territorial sponsored a workshop involving biologists and management authorities and produced a management plan for T. c. callirostris (MAVDT 2009). 
Hopefully this indicates that more substantive monitoring and management activities will be implemented soon.

In Colombia, the only protected area within the range of T. c. callirostris is the Ciénaga Grande de Santa Marta Fauna and Flora Sanctuary, a Ramsar site that is a complex of 20 lakes along the Caribbean coast with differing levels of salinity. The southern-most portions of this area are affected during annual flooding by waters from the Magdalena River drainage and probably represent the best habitat for this subspecies within the sanctuary. In Venezuela, the Ciénagas de Juan Manuel National Park is located on the western shore of Lake Maracaibo, within the known range of $T$. $c$. callirostris, while a complex of protected areas made up of the Morrocoy National Park, Tucurere Wildlife Refuge, and Cuare Wildlife Refuge (a Ramsar site) occur within the known range of $T$. c. chichiriviche.

In Colombia, several community-based conservation projects for T.c.callirostris have been funded in recent years that have experimented with setting harvest limits (Angel-V. 2002; Dydime-Dome and Mejia 2003) and head-starting (De la Ossa 2002), but we are unaware of any such efforts in Venezuela for either T. c. callirostris or T. c. chichiriviche.

Conservation Measures Proposed. - To date, the specific data needed to justify recommending a higher IUCN category for T.callirostris have not been available, despite the anecdotal accounts of local extirpations or density declines obtained from residents in various parts of the range of the species. However, our studies showing that higher hunting pressures significantly affect size distributions in nesting females, thereby reducing their reproductive potentials (Bernal et al. 2004; Daza 2004; Daza and Páez 2007), is indirect evidence that current levels of exploitation in many areas is no longer sustainable. The effects of substantial adult sex ratio biases brought about by hunting that is directed selectively towards the largest adult females may be a concern as well. We suspect that when demographic monitoring is conducted, it will show that most populations are experiencing declines. The low level of genetic variability documented in $T$. $c$. callirostris is also of concern (Martinez et al. 2007). All of this evidence suggests that the status of T.callirostris should probably be elevated to Vulnerable on the IUCN Red List, but at present, specific data are lacking.

Protected areas exist in both Colombia and Venezuela within the range of T.c. callirostris and also in Venezuela within the range of $T$. c. chichiriviche. Even so, it would be desirable to create another reserve in the Magdalena or Sinú drainages to provide more protection not only for T. callirostris populations, but also other species such as Podocnemis lewyana and Rhinoclemmys melanosterna. While laudable, the limited enforcement activities of environmental authorities in Colombia (confiscating turtles discovered while being transported to or when on sale in markets) are of concern, because these individuals are released into habitats without knowing their origin.

Captive Husbandry. - Information concerning captive rearing and breeding has been published for both $T$. $c$. callirostris (ter Borg 1980; Helm and Giebner 1998; Hennig et al.2006) and T.c.chichiriviche (Naths and Hennig 2005). De la Ossa and Riaño-S. (1999) also published a guide to captive rearing and breeding of T.c.callirostris in Colombia that included a list of 31 locally available plants suitable as diet items, and an economic analysis of the expected profits to be obtained from such a venture. The only reptile farm in Colombia currently licensed to produce $T$. c. callirostris for commercial purposes is the Zoocriadero Los Zambos in the Córdoba Department of Colombia.

Current Research. - The Instituto de Genética of the Universidad Nacional de Colombia has been contracted by the Ministerio de Ambiente, Vivienda, y Desarrollo Territorial to produce a genetic data base of key Colombian wildlife species, including T. callirostris, to provide guidance to government officials on where to release confiscated individuals. The Grupo Herpetológico de Antioquia also has initiated a turtle monitoring project in the Magdalena River drainage near Puerto Berrio that includes T. callirostris.

Remarks. - One justification of Seidel (2002) for elevating the subspecies of T.scripta (sensu lato) to specific status was that this could improve the conservation status of subspecies in countries where legislation is still limited to the species level (rather than directed at subspecies or ESUs). The notion of basing taxonomic decisions on conservation considerations has been criticized on scientific grounds (Sites and Crandall 1997; Karl and Bowen 1999), but practical considerations also exist. First, the argument of Seidel (2002) supposes that by elevating the conservation status of vulnerable phylogenetic units by promoting their recognition as valid, more endemic species, this will translate into improved protection for them. But in many of the countries where conservation legislation is still directed only at the species level, not even those species assigned to the highest categories of threatened status receive any serious protection. On the other hand, another consequence of elevating $T$. callirostris to species status that we have experienced is in terms of its study. By now being able to say it is a heavily exploited species nearly endemic to Colombia (instead of a heavily exploited subspecies of a common, wide-ranging species), we may have had better success recently in funding our research efforts on this taxon. Unfortunately, we also feel it has had a negative effect in terms of the chances of success and the effort needed to obtain research permits from governmental authorities.

Acknowledgments. - We would like to thank M. Rivera-C. for providing information on the legally approved commercial turtle farming venture in Colombia and the Universidad de Antioquia for financial and logistic support of our recent studies on T. c. callirostris.

\section{LITERATURE CITED}

Aguilera-G. 1998. Informe socioeconómico de la comunidad de Isla de Coco. Proyecto de Caracterización del Uso de la Fauna y Flora en la Región de la Mojana. Corpoica, Programa Nacional 
de Agroecosistemas. Bogota, Colombia.

AgILERA-G. and NeIRA-M., F.H. 1999. Proyecto caracterización biofísica, socioeconómica y tecnológica, de los sistemas de producción agropecuarios de la región de La Mojana. Capítulos Sistema de producción de pesca y caza y Caracterización del uso de fauna y flora. Final report. Corpoica, Programa Nacional de Agroecosistemas. Botoga, Colombia.

ANGEL-V., C.E. 2002. Diseño e implementación de un sistema de cuotas de extracción de la tortuga icotea (Trachemys scripta callirostris) en la región de La Mojana, Sucre. Programa de Desarrollo Sostenible de la Región de La Mojana. Organización de las Naciones Unidas para la Agricultura y la Alimentación. Bogotá, Colombia.

Bernal, M.2003. Informe Final.Caracterización de las Poblaciones de la Iguana Verde (Iguana iguana) y apoyo del desarrollo de la primera fase de monitoreode la tortuga hicotea (Trachemys scripta callirostris). Instituto de Investigación de Recursos Biológicos Alexander von Humboldt, Bogotá, Colombia.

BERNAL, M., DAZA, J.M., AND PÁEZ, V.P. 2004. Ecología reproductiva y cacería de la tortuga icotea Trachemys scripta callirostris (Testudinata: Emydidae), en elárea de la Depresión Momposina, norte de Colombia. Revista de Biología Tropical 52:229-238.

BoulENGER,G.A. 1889. Catalogue of the chelonians, rhynchocephalians, and crocodiles in the British Museum (Natural History). Taylor and Francis, London, UK.

Buhlmann, K.A., Akre, T.S., Iverson, J.B., Karapatakis, D., MitTERMEIER, R.A., GEORGES, A., RHODIN, A.G.J., vAN DiJK, P.P., AND GibBons, J.W. 2009. A global analysis of tortoise and freshwater turtle distributions with identification of priority conservation areas. Chelonian Conservation and Biology 8(2):116-149.

Castaño-Mora, O.V. 2002. Libro Rojo de Reptiles de Colombia. Libros Rojos de Especies Amenazadas de Colombia. Instituto de Ciencias Naturales-Universidad Nacional de Colombia, Ministerio de Medio Ambiente, Conservación Internacional-Colombia. Bogotá, Colombia.

Close, L.M. And Seigel, R.A. 1997. Differences in body size among populations of red-eared sliders (Trachemys scripta elegans) subjected to different levels of harvesting. Chelonian Conservation and Biology 2:563-566.

Correa-H.,J.C.2006. Ecología reproductiva de las tortugas Podocnemis lewyana (Podocnemidae) y Trachemys callirostris callirostris (Emydidae) en Isla Pava, Ciénega La Riconada, Depresión Momposina, Colombia. Undergraduate Thesis, Instituto de Biología, Universidad de Antioquia, Medellín, Colombia.

DAZA, J.M. 2004. Variación morfométrica y su relación con el potencial reproductivo en siete subpoblaciones de Trachemys callirostris callirostris (Testudines: Emydidae) en la Depresión Momposina, Norte de Colombia. Master's Thesis, Instituto de Biología, Universidad de Antioquia, Medellín, Colombia.

DAZAJ.M. ANDPÁEZ, V.P. 2007. Morphometric variation and its effect on reproductive potential in female Colombian slider turtles (Trachemys callirostris callirostris). Herpetologica 63:125-134.

De la Ossa, J. 2002. Informe Final de Actividades. Proyecto Desarrollo Tecnológicopara laZoocríaArtisenal de Hicotea(Trachemys scripta callirostris), en la Granja Experimental de la Universidad de Sucre y posterior capacitación en el Municipio de San Marcos, zona sur del Departamento de Sucre, Colombia. Ministerio de Agricultura y Desarrollo Rural, Bogotá, Colombia.

De LAOssa,J.L.2003.Manejode fauna silvestre tropical.In: Programa de Desarrollo Sostenible de la Región de La Mojana.Departamento Nacional de Planeación, Bogotá, Colombia, pp. 62-74.

De la Ossa, J.L. and Riaño-S., R. 1999. Guía para el manejo, cría y conservación de la hicotea o jicotea Trachemys scripta callirostris
(Gray). Convenio Andrés Bello. Serie Ciencia y Tecnología No. $74,40 \mathrm{pp}$.

Dydime-Dome, D. And MeJia, A. 2003. Aprovechamiento sostenible de hicoteas, patos pisingos e iguanas en la Ciénaga de Bañó, Cocotá-Arriba, Lorica, Departamento de Córdoba. Instituto de Investigación de Recursos Biológicos Alexander von Humboldt, Bogotá, Colombia.

ERNST, C.H. 1990. Systematics, taxonomy, variation, and geographic distribution of the slider turtle. In: Gibbons, J.W.(Ed.).Life History and Ecology of the Slider Turtle. Washington, DC: Smithsonian Institution Press, pp. 57-67.

ERnst, C.H. 2003. Trachemys callirostris. Catalogue of American Amphibians and Reptiles. 768:1-4.

FritZ, U. AND HaVAš, P. 2007. Checklist of Chelonians of the World. Vertebrate Zoology 57:149-368.

Fuentes-O., S., SAmPedro-M., A., AND Ardila-M., M. 2003. Importancia de la jicotea (Trachemys scripta callirostris: Chelonia, Emydidae) como recurso natural en la comunidad de Isla de Coco, región de la Mojana, Departamento de Sucre, Colombia. Revista Biológica 17:126-133.

Gärdenfors, U., Hilton-TAylor, C., Mace, G., and Rodríguez, J.P. 2001. The application of IUCN Red List Criteria at regional levels. Conservation Biology 15:1206-1212.

GibBons, J.W. (ED.). 1990. Life History and Ecology of the Slider Turtle. Washington, DC: Smithsonian Institution Press, 368 pp.

Gray, J.E. 1856. Catalogue of the shield reptiles in the collection of the British Museum. Part I. Testudinata (Tortoises). British Museum (Natural History), 79 pp.

Helm, W. and GiebneR, I. 1998. Haltung und Vermehrung der Kinnflecken-Schmuckschildkröte Trachemys dorbigni callirostris. Journal der AG Schildkröten 7:21-27.

Hennig, A.S., NATHs, V., AND Helm, W. 2006. Husbandry and propagation of the Colombian slider,Trachemys callirostris callirostris (Gray 1856). Radiata 15:23-31.

IVERSON,J.B. 1982. Biomass in turtle populations: a neglected subject. Oecologia 55:69-76.

IVERSON, J.B. 1992. A Revised Checklist with Distribution Maps of the Turtles of the World. Richmond, Indiana: Privately printed, $363 \mathrm{pp}$.

Jackson, J.T., Starkey, D.E., Guthrie, R.W., And Forstner, M.R.J. 2008. A mitochondrial DNA phylogeny of extant species of the genus Trachemys withresulting taxonomicimplications. Chelonian Conservation and Biology 7:131-135.

KARL, S.A. AND BowEN, B.W. 1999. Evolutionarily significant units and geopolitical taxonomy: molecular systematics of an endangered sea turtle (genus Chelonia). Conservation Biology 13:990-999.

LEGLER,J.M. 1990.The genus Pseudemys in Mesoamerica: taxonomy, distribution, and origins. In: Gibbons, J.W. (Ed.). Life History and Ecology of the Slider Turtle. Washington, DC: Smithsonian Institution Press, pp. 82-105.

LenIs, C. 2009. Trematodos y moluscos asociados a Podocnemis lewyana y Trachemys callirostris callirostris (Testudinata) de la Depresión Momposina, Colombia. Masters Thesis, Instituto de Biología, Universidad de Antioquia, Medellín, Colombia.

Lenis, C. And Garcia-P., L. 2009. Polystomoides magdalenensis n. sp. (Monogenoidea: Polystomatidae), a parasite of buccal cavity of Trachemys callirostris callirostris (Testudinata: Emydidae) from Colombia. Journal of Parasitology 95:850-854.

Martinez,L.M.,Bock,B.C., ANDPÁEZ,V.P.2007.Population genetics of the slider turtle (Trachemys scripta callirostris) in the Mompos Depression, Colombia. Copeia 2007:905-908.

MAVDT. 2009. Plan de Manejo orientado al Uso Sostenible de la Tortuga Hicotea en Colombia. Ministerio de Medio Ambienta, 
Vivienda, y Desarrollo Territorial. Bogota, Colombia.

Medem, F. 1975. La reproducción de la "icotea" (Pseudemys scripta callirostris), (Testudines, Emydidae). Caldasia 11:83-101.

Methner, K. 1989. Die Schildkröten des unteren Rio Magdalena (Kolumbien). Sauria 11:9-11.

Moll, D. 1990. Population sizes and foraging ecology in a tropical freshwater stream turtle community. Journal of Herpetology 24:48-53.

Moll, E.O. AND LeGLeR, J.M. 1971. The life history of a neotropical slider turtle, Pseudemys scripta (Schoepff), in Panama. Bulletin of the Los Angeles County Museum of Natural History 11:1-102.

MüLLER,L. 1940. Über Pseudemys callirostris (Gray). Tier und Umwelt Sudamerika. Ibero-Amerikanische Studien 13:108-126.

Muñoz, E.M., Ortega, A.M., Bock, B.C., AND PÁEz, V.P. 2003. Demografía y ecología de la iguana verde, Iguana iguana (Squamata: Iguanidae), en dos poblaciones explotadas en la Depresión Momposina, Colombia. Revista de Biología Tropical 51:229-240.

Naths, V. and Hennig, A.S. 2005. Notes on the husbandry of the Venezuelan slider,Trachemys callirostris chichiriviche (Pritchard and Trebbau, 1984). Radiata 14:20-24.

Pritchard, P.C.H. And TrebBau, P. 1984. The Turtles of Venezuela. Contributions to Herpetology, No. 2. Society for the Study of Amphibians and Reptiles, Oxford, Ohio, USA.

RAND, A.S. 1968. A nesting aggregation of iguanas. Copeia 1968:552-561.

Restrepo, A., Piñeros, V.J., AND PÁez, V.P.. 2006. Nest site selection by female Trachemys callirostris (Testudinata: Emydidae) in the Mompos Depression of Colombia. Chelonian Conservation and Biology 5:249-253.

Restrepo, A., Piñeros, V.J., AND PÁEz, V.P. 2007. Características reproductivas de la tortuga Trachemys callirostris callirostris (Testudinata: Emydidae) en Isla León, Depresión Momposina, Colombia. Caldasia 29:1-17.

RuEda-Almonacid, J.V., CARR, J.L., MitTermeIER, R.A., RodríGuEZMahecha, J.V., Mast, R.B., Vogt, R.C., Rhodin, A.G.J., De LA Ossa-Velásquez,J.,RuedA,J.N., AND MitTermeier,C.G.2007.Las Tortugas y los Cocodrilianos de los Países Andinos del Trópico. Bogotá, Colombia: Editorial Panamericana, Formas e Impresos, Serie de Guías Tropicales de Campo No. 6, Conservación Internacional, $538 \mathrm{pp}$.

SAMPEDRO-M.,A.,Ardila-M.,M.,ANDFuENTES-O.,S.2003.Aspectos de la morfometría de la jicotea colombiana (Trachemys scripta callirostris: Chelonia, Emydidae) y sus posibles ventajas para la supervivencia. Revista Biológica 17:114-119.

Santos, P.L. and Huertas-A., B.M. (Eds.). 2003. Programa de Desarrollo Sostenible de la Región de La Mojana. Departamento
Nacional de Planeación, Bogotá, Colombia.

SCRIBNER, K.T., Smith, M.H., AND GibBons, J.W. 1984. Genetic differentiation among local populations of the yellow-bellied slider turtle (Pseudemys scripta). Herpetologica 40:382-387.

Scribner, K.T., Evans, J.E., Morreale, S.J., Smith, M.H., And GibBons, J.W. 1986. Genetic divergence among populations of the yellow-bellied slider turtle (Pseudemys scripta) separated by aquatic and terrestrial habitats. Copeia 1986:691-700.

SEIDEL, M.E. 2002. Taxonomic observations on extant species and subspecies of slider turtles, genus Trachemys. Journal of Herpetology 36:285-292.

SITES,J.W.,JR. AND CRANDALL,K.A.. 1997. Testing species boundaries in biodiversity studies. Conservation Biology 11:1289-1297.

Smith, M.H. And Scribner, K.T. 1990. Population genetics of the slider turtle. In: Gibbons, J.W. (Ed.). Life History and Ecology of the Slider Turtle. Washington, DC: Smithsonian Institution Press, pp. 74-81.

StePHENS, P.R. And Weins, J.J. 2003. Ecological diversification and phylogeny of emydid turtles. Biological Journal of the Linnean Society 79:577-610.

TER BORG,J.P. 1980.Dekinvlekpauwoogschildpad Chrysemys scripta callirostris. Lacerta 39:31-32.

Turtle Taxonomy Working Group [Bickham, J.W., IVerson, J.B., Parham, J.F., Philippen, H.D., Rhodin, A.G.J., Shaffer, H.B., SPINKS, P.Q., AND VAN DIJK, P.P.] 2007. An annotated list of modern turtle terminal taxa with comments on areas of taxonomic instability and recent change. In: Shaffer, H.B., FitzSimmons, N.N., Georges,A., and Rhodin, A.G.J.(Eds.). Defining Turtle Diversity: Proceedings of a Workshop on Genetics, Ethics, and Taxonomy of FreshwaterTurtles and Tortoises.Chelonian ResearchMonographs No. 4, pp. 173-199.

WARWICK, C. 1986. Red-eared terrapin farms and conservation. Oryx 20:237-240.

\section{Citation Format for this Account:}

Bock, B.C.,PÁEz, V.P., AND DAZA, J.M. 2010.Trachemys callirostris (Gray 1856) - Colombian slider, jicotea, hicotea, galapago, morrocoy de agua.In: Rhodin,A.G.J.,Pritchard,P.C.H., van Dijk,P.P., Saumure, R.A., Buhlmann, K.A., Iverson, J.B., and Mittermeier, R.A. (Eds.). Conservation Biology of Freshwater Turtles and Tortoises: A Compilation Project of the IUCN/SSC Tortoise and Freshwater Turtle Specialist Group. Chelonian Research Monographs No.5,pp.042.1-042.9, doi:10.3854/crm.5.042.callirostris. v1.2010, http://www.iucn-tftsg.org/cbftt/. 